\title{
Determining the Factors That Influence Migrant Worker Remittance: A Gulf Cooperation Council Case Study
}

\author{
Ahmed Alnuaimi, Fatimah Salwa binti Abd. Hadi \& Norimah Rambeli @ Ramli \\ Faculty of Management \& Economics, \\ University Pendidikan Sultan Idris, Perak Malaysia \\ Email: fatimahsalwa@fpe.upsi.edu.my \\ DOI: https://doi.org/10.37134/jcit.vol7.2.2017
}

\begin{abstract}
This paper examines and evaluates the macroeconomics factors driving the workers' remittance flows from GCC countries to eight Middle East and South Asian Countries during period 1989 to 2010. The gravity model has approached to estimate remittances, utilizing a variety of panel data techniques. The estimator indicates that remittances respond more to GCC (host countries) macroeconomics activities, than to changes in the macroeconomic activities in the Middle East and South Asian Counties (home countries). The results also show the differential in the wage rates between the GCC countries and the Middle East and South Asian counties had a significant positive effect on remittance flows. However, the estimator also indicates distance was not a significant proxy to impact on the remittance flows.
\end{abstract}

Keywords Remittances, GCC, Stock of migrants, Gravity Model, Middle East

\section{Introduction}

Remittances, in their most general usage, are the transfer of a portion of a migrant worker's wages back to his or her family. According to the World Bank and the International Monetary Fund, the remittances sent through formal, and informal channels are $50 \%$ more than the official aid provided to the developing countries. In fact, World Bank (2009) has shown, remittances flows are the second largest source behind Foreign Direct Investment, of external funding for developing, and this is via formal channels but if takes into consideration informal channels, the remittances are larger than (FDI).Figure 1 shows that the formal workers' remittances among other international financial sources during period 1991-2010.

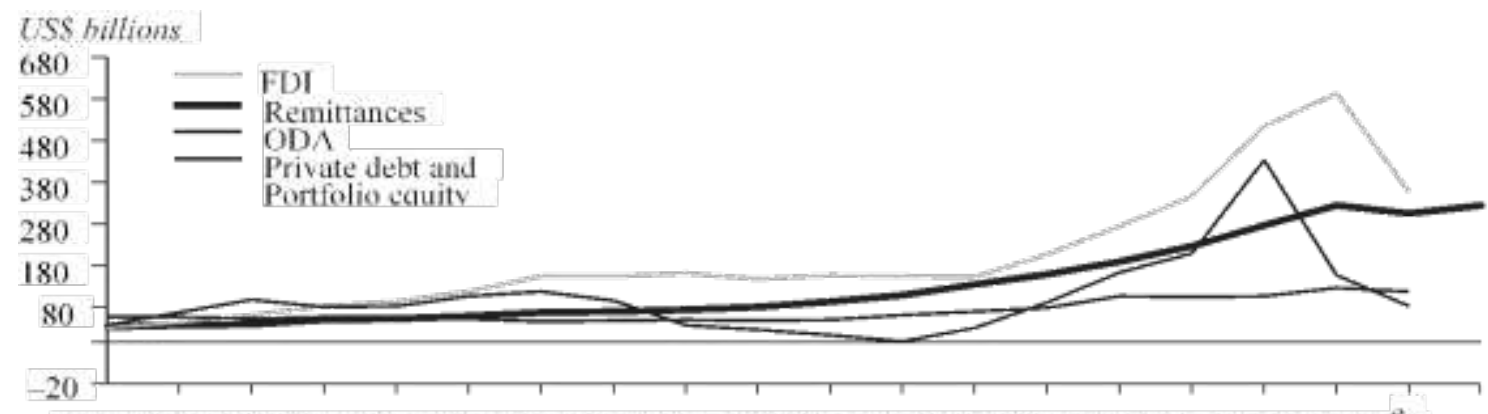

$199119921993199419951996199719981999 \quad 2000001200220032004200520062007200820062010$

Sources: World Development Indicators database and World Bank Migration and Remittances Unit.

Note: Private debt includes only medium- and long-term debt. FDI = foreign direct investment; ODA $=$ official development assistance; $-=$ not available.

Figure 1 Remittances Compared with Other Resource Flows 


\subsection{Statement of the Problem}

The Gulf Cooperation Council (GCC) is an economic and political union of six countries in the Arabian Peninsula overlooking the Persian Gulf. The Union started in 1981 with Saudi Arabia, Qatar, Oman, Bahrain, Kuwait and the UAE as its members (Kapiszewski, 2006).

Naufal and Termos (2009) found a unique feature, in that the population of expatriates in the GCC countries surpassed $70 \%$ of their total population. This implies that $70 \%$ of people living in the region were not born in the region. In addition, 2010 United Nations (UN) report suggested that labourers from Asian countries, such as India, Pakistan, Bangladesh, the Philippines and Indonesia, started coming to the GCC countries in 1975. The percentage of the migrant workforce in the GCC countries grew from approximately 39\% in 1975 to $70 \%$ in 2005. The period between 1980 and 1995 represented a peak period for employing migrant workers. Table 1 illustrates the average growth in the number of migrant workers in the GCC from 1975 to 2005.

Table 1 Percentage of expatriate workers in the labour force of the GCC countries from 1975 to 2000

\begin{tabular}{|c|c|c|c|c|c|c|c|c|}
\hline \multirow[b]{2}{*}{$\begin{array}{l}\text { GCC } \\
\text { Countries }\end{array}$} & \multicolumn{2}{|c|}{1975} & \multicolumn{2}{|c|}{1985} & \multicolumn{2}{|c|}{1995} & \multicolumn{2}{|c|}{2005} \\
\hline & $\begin{array}{l}\text { No. } \\
\left(000^{\prime} s\right)\end{array}$ & $\begin{array}{c}\% \text { of } \\
\text { Expatriates }\end{array}$ & $\begin{array}{l}\text { No. } \\
\left(000^{\prime} s\right)\end{array}$ & $\begin{array}{c}\% \text { of } \\
\text { Expatriates }\end{array}$ & $\begin{array}{l}\text { No. } \\
\left(000^{\prime} s\right)\end{array}$ & $\begin{array}{c}\% \text { of } \\
\text { Expatriates }\end{array}$ & $\begin{array}{l}\text { No. } \\
(000 \text { 's })\end{array}$ & $\begin{array}{c}\% \text { of } \\
\text { Expatriates }\end{array}$ \\
\hline Saudi Arabia & 1,924 & 25.2 & 4,342 & 62.7 & 6,450 & 63.5 & 7,176 & 55.8 \\
\hline UAE & 279 & 84.0 & 865 & 90.6 & 1,088 & 89.8 & 1,356 & 89.8 \\
\hline Kuwait & 305 & 81.8 & 670 & 85.7 & 1,052 & 83.4 & 1,320 & 80.4 \\
\hline Oman & 225 & 31.1 & 369 & 51.8 & 670 & 64.2 & 859 & 64.3 \\
\hline Qatar & 69 & 83.0 & 100 & 76.5 & 218 & 82.1 & - & 90.0 \\
\hline Bahrain & 60 & 81.8 & 171 & 57.9 & 227 & 60.0 & - & 54.0 \\
\hline Total & 2,861 & 39.0 & 6,518 & 68.2 & 9,705 & 74.0 & - & 64.0 \\
\hline
\end{tabular}

Source: United Nations, 2010.

Similarly, Taghavi (2012) identified that the GCC migrant workers came from three major sub-regions of Asia: the Far East (the Philippines and Indonesia), the MENA (North Africa and the Middle East, including Syria, Yemen, Egypt and Jordan) and the Near East (Bangladesh, Pakistan and India). Consequently, most of the outflow remittances from the GCC countries went to these regions. Table 2 highlights, according to Taghavi (2012), the share of remittance outflows from 1990 to 2010 from the GCC countries by region, tabulated in time blocks.

Table 2 Share of remittances from the GCC by region of origin

\begin{tabular}{ccccc}
\hline Time series & $\begin{array}{c}\text { MENA } \\
(\%)\end{array}$ & $\begin{array}{c}\text { Near East } \\
(\%)\end{array}$ & $\begin{array}{c}\text { Far East } \\
(\%)\end{array}$ \\
\hline 1990 & 1995 & 45.0 & 24.0 & 31.0 \\
1995 & 2000 & 23.0 & 27.0 & 50.0 \\
2000 & 2005 & 15.0 & 36.0 & 49.0 \\
2005 & 2010 & 10.0 & 44.0 & 46.0 \\
\hline
\end{tabular}

Source: Taghavi (2012). Note: MENA = Middle East and North Africa. 
Table 2 shows that until 1995, workers from the Middle East and North Africa (MENA) received up to 45 per cent of the total share of remittances; this was followed by the Near East and the Far East. However, the share of the remittances of the MENA countries declined rapidly, reaching merely 10 per cent in 2010, while remittance outflows from the GCC countries into the two other regions (the Far East and the Near East) almost doubled by 2010. This indicates that the volume of the work force migrating from the Near East and the Far East regions (e.g. Pakistan, India, Bangladesh, Philippines, Sri Lanka and Indonesia) into the GCC, increased rapidly from 1995 to 2010.

Moreover, according to the Word Bank (2010), the aggregate level of remittance outflows from the GCC countries was over US $\$ 60$ billion, which represented an average of $7.5 \%$ of GCC GDP. For example, in 2010, Saudi Arabia was the second highest remitting country in the world, second only to the US. The value of the remittances from Saudi Arabia in 2010 was estimated at US \$15.4 billion, placing it next to Kuwait, Oman and the US (Table 3).

Table 3 Key Remittance Value Sources and Recipient Countries

\begin{tabular}{lclc}
\hline Source country & $\begin{array}{c}\text { US } \$ \\
\text { (Billion) }\end{array}$ & Recipient Country & $\begin{array}{c}\text { US \$ } \\
\text { (Billion) }\end{array}$ \\
\hline US & 20.7 & India & 7.7 \\
Saudi Arabia & 15.4 & France & 6.9 \\
Germany & 8.8 & Mexico & 5.7 \\
Switzerland & 8.1 & Philippines & 5.0 \\
France & 4.9 & Germany & 4.1 \\
Italy & 2.2 & Portugal & 3.8 \\
Israel & 2.1 & Egypt & 3.8 \\
Belgium/Luxembourg & 1.8 & Turkey & 3.7 \\
Kuwait & 1.4 & Spain & 3.0 \\
Oman & 1.4 & Greece & 2.7 \\
\hline Source: IMF, BOP Statistics (Annual average, 1992-2010) & & \\
\hline
\end{tabular}

Despite the importance of the workers' remittances especially from GCC region as everincreasing size of remittance flows, to date, very little attention has been paid onto this region. In fact, there is a lack of empirical evidence on the determinants' of workers' remittance flows from GCC countries. No studies have been carried out to determine the factors affecting the remittances of workers residing in the Gulf region. Therefore, this study fills this gap and contributes to the literature in two ways. First, it examines and evaluates the GDPs and GDPs per capita in home and host countries if they can influence on the remittance flows from GCC .Second, the study at a first time, contributes to literature, by testing the hypothesis whether non-macroeconomic factors can influence into increase or decrease remittance flows from GCC region.

\subsection{Objectives of the Study}

The study seeks to determine the factors influence the nature and extent of workers' remittance flows using a case study of the Gulf Cooperation Council. More specific, the major three objectives will be as follows:

i. To provide a valuable comparison of GCC countries with South Asian and Middle Eastern countries in terms of the volume of remittance flows, economic activities and stock of 
emigrants by using time series 1989-2010.

ii. To investigate whether GDP and GDP per capita are correlated to increase or decrease remittance flows from GCC countries.

iii. To examine the non- macroeconomic factors if they can influence remittance flows from GCC countries.

\section{Methodology and Data Collection}

The study contributes to a new data set approach of bilateral remittance flows for developing countries and estimates a gravity model for workers' remittances. The gravity model is one of the most empirically successful in economics. It has been widely used to infer trade two effects of institutions such as customs unions, exchange rate mechanisms, linguistic identity and international borders. The theory has developed by Anderson (1979), who advises that after controlling for size, trade between two regions is decreasing in their bilateral trade barrier relative to the average barrier of the two regions to trade with all their partners. This study, for the first time, estimates a gravity model for workers' remittances from 6 GCC countries. The first study of remittances uses a gravity approach was done by Lueth and Arranz (2006).

According to Lueth and Arranz (2006) results, the gravity framework is very powerful in explaining remittance flows. In fact, a few gravity variables such as partner countries' GDP, distance, common border, and common language can explain more than 50 percent of the variation in remittance flows across time and countries".

The study takes a similar approach of that one Lueth and Arranzee (2006) and Ahmed et al, (2014). Firstly, it applies a gravity model, typically used to describe trade and, recently, to describe workers' remittances. It takes six GCC sending countries to examine workers' remittances in eight recipient countries. Those eight countries divided into three primary regions; Far, Near and Middle East. The Far East countries are Philippians and Indonesia, while Near East countries are India, Pakistan and Bangladesh. Middle East countries are Egypt, Jordan, and Syria .Secondly, it will show how some Dummy variables such as a general language, distance and shared border can influence on of workers' remittance outflows.

\subsection{Empirical Analysis}

The study uses the augmented gravity model as the theoretical framework. Panel data techniques has used to examine the factors that influence the remittance flows from the six GCC countries (e.g. the UAE, Oman, Bahrain, Qatar, Kuwait and Saudi Arabia) to eight South Asian and Middle Eastern countries (e.g. Bangladesh, India, Indonesia, Pakistan, the Philippines, Gordon, Egypt and Syria) from 1989 to 2010.

The gravity equation for trade states that trade flows between two countries are proportional to the two countries' economic sizes (GDPs) and inversely proportional to the distance between them. The model includes variables to account for income level (GDP per capita) and physical and cultural proximity (shared border, language relationship, and colonial history). The proposed empirical analysis is based on an balanced panel over the period 1989-2010 to assess the independent variables GDPs, GDPs per capita and some Dummy variables from country $i$ to country $j$ at time period $t$. The proposed technique is a regression analysis technique.

$$
\operatorname{InREM}_{j i t}=B_{1} \operatorname{InGDP_{ij}}+B_{2} \operatorname{In} G D P_{i j}+B_{3} \operatorname{InDis} s_{i j}+\operatorname{In} X_{i j t}+e_{j i t}(1)
$$

where: REMjit refers to the level of the REM outflows in dollars from the sending country $\mathrm{j}$ to 
the recipient country $\mathrm{i}$ in year $\mathrm{t}$. The explanatory variables GDPjt and GDPrt indicate the nominal gross domestic products of the sending country $j$ and of the receiving country $i$ in year $t$. Distji measures the physical distance between the capitals of the countries $j$ and $i . X$ refers to a number of control variables.

The paper analysis has conducted by using a variety of methods. First, the Augmented Dickey Fuller (ADF) method has used to test whether each variable in the study has a unit root or not. If a unit root exists among the time series variables, it would imply that the data is not stationary, and therefore, other techniques have used. The differencing techniques, including the first difference (level one) and second difference (level two) techniques, have applied. These techniques are typically used to transform non-stationary time series data into stationary time series data. Second, to study the effect of the explanatory variables on remittance, the four model specifications were explored as a benchmark. There models were: Pooled OLS estimates, Fixed effect for sending and receiving country, random effect for country-pairs and Mundlak's approach with random effects for country-pairs (Ahmed et al, 2014).

\subsection{Variable Description}

Gross Domestic Product (GDP). The GDP variable considers an important factor in influencing remittance flows. The study took GDPs for six GCC countries as sources countries Vs GDPs for eight as recipient country time series 1989-2010 in millions of US dollars. The GDP is the most obvious factor that influences higher remittances to recipient countries (Vargas and Huang, 2006). In general, improved economic conditions in the source country allow migrant has to enhance both their employment and earnings prospects and hence, send more remittances. The expected sign of the economic activity in the source countries is expected to be positive, regardless of the motivation of the migrant to remit. (See Akkoyunlu and Kholodilin (2006), Lueth and Arranz (2006), Ahmed et al, (2014), Ramon et al (2011),Barua,et al, (2007), Vergas-Silva and Huang (2006))

GDP Per Capita. The second explaining factor is the income level (measured in term of GDP) in the recipient country, which has an ambiguous effect on remittances depending on the prevailing motive to remit. Therefore, the study took GDPs per capita for 6GCC countries Vs GDPs per capita for 8 counties -1989-2010 times series and in Million dollars.(See Akkoyunlu and Kholodilin (2006), Lueth and Arranz (2006), Ahmed et al, (2014), Ramon et al (2011),Barua,et al, (2007), Vergas-Silva and Huang (2006))

Distance is a proxy for many elements, such as transportation costs, transaction costs, historical relationship as well as the period for the delivery of shipment of goods.The study describes physical distance and transaction cost. Geographical distance is measured as the distance from, each country in GCC country to each country in 8 country -e.g. KSA to BGD, KSA to Pak, KSA to IND and so on. The usual measure of this variable is the distance among the capital cities of trading partners.The variable comes from the CEPII database. The geographical distance variable has been commonly used to proxy the transaction costs of remitting. The existing evidence concerning the sign and significance of the relationship between remittances and geographical distance is mixed. Some studies argued that remittances are positively related to physical distance, which country closer receive more remittances, as reported by Lueth and Arranz (2006). However, this was not consistent with Ahmed et al, (2014) findings. These authors found the coefficient of this variable is expected to be negative, as greater distances will incur higher transportation costs.

Common languages dummies, the study uses common two countries share a common official language, and the other one set to one if a language is spoken by at least $9 \%$ of the population in both countries. Colonization is here a fairly general term that we use to describe 
a relationship between sources of country and recipient country.

\subsection{Data Sources}

Data on bilateral remittance flows are an important shortcoming in the analysis of the determinants of workers' remittances. The IMF balance of payments statistics, IMF annual reports, World Bank annual reports and some central banks' data are main data source on remittances. Data from the following sources: World Economic Outlook (WEO), International Financial Statistic (IFS), World Development Indicators (WDI) and Andrew Rose's website have also considered. The table 4 shows the summary of number of variables observation, sources and expected sign.

Table 4 Summary of the number of variables observation, sources and expected sign

\begin{tabular}{|c|c|c|c|}
\hline Description & Variable Name & Source & Expected Sign \\
\hline \multirow{4}{*}{$\begin{array}{l}\text { *Y= Dependant } \\
\text { In Rem } \\
\text { Sources Countries } \\
\text { GCC Region- KSA,UAE } \\
\text { OMN BHR ,KWT and } \\
\text { QTR }\end{array}$} & GCC remittance outflows & $\begin{array}{l}\text { IMF Annual reports of Balance of } \\
\text { payment, Central Banks and World Bank }\end{array}$ & \\
\hline & & & \\
\hline & GDPs of GCC countries & WEO and IMF and Word Bank indicators & Positive \\
\hline & GDPs per capita & IMF and World Bank & Positive \\
\hline \multirow{3}{*}{$\begin{array}{l}\text { Recipient Countries } \\
\text { - Pak , BGD , IND, and } \\
\text { Southern Asia countries- } \\
\text { PHL and IDO and } \\
\text { Middle East countries- } \\
\text { JOR, SYR and EGY }\end{array}$} & GDPs of Southern Asian & & \\
\hline & Countries \&Middle East & WEO and IMF & Negative \\
\hline & GDPs per capita & IMF and World Bank & Negative \\
\hline \multirow{3}{*}{$\frac{\text { Dummy variable }}{\text { Common language }}$} & Common Language between & IMF and WEO & \\
\hline & 6GCC to Middle East \& & & \\
\hline & & & Positive/Nega \\
\hline Distance & $\begin{array}{l}\text { Distance between } 6 \text { GCC to } \\
\text { Middle East \& South Asian }\end{array}$ & Andrew Rose's website; \& CEPII & Positive / Nega \\
\hline
\end{tabular}

\section{Results}

The study has examined the macroeconomic indicators as well as non-macroeconomics indicators that influenced the remittances from six GCC countries to eight Middle East and South Asian countries (e.g. Bangladesh, India, Indonesia, Pakistan, the Philippines, Gordon, Egypt and Syria) from 1989 to 2010. Therefore i) it provided a valuable comparison of GCC region with South Asian and Middle Eastern regions in terms of the volume of remittance flows. ii) It also assessed whether GDP and GDP per capita are correlated to increase or decrease remittance flows from GCC countries. iii) It has also examined the nonmacroeconomic factors if they can influence remittance flows from GCC countries.

Figures 2 demonstrates bilateral remittances between GCC and the recipient countries increased at about the same rate over time for most country-pairs though the changes over time were steeper for some country-pairs. 


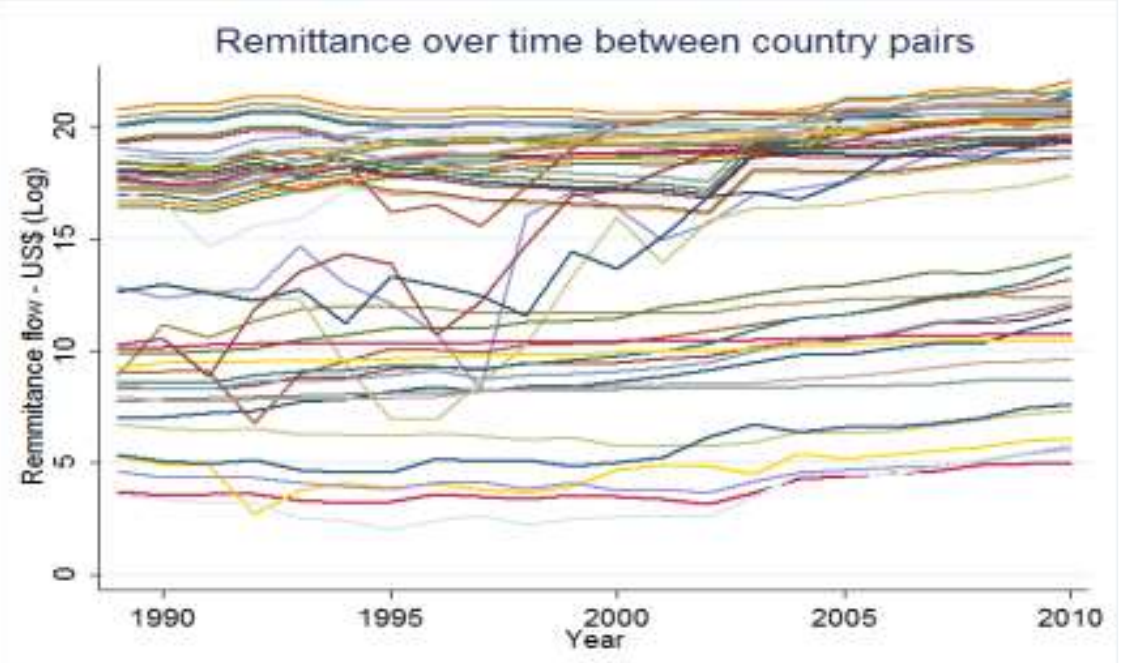

Figure 2 Remittance flows from GCC over time 1990-2010

Panel data techniques has used to examine the factors that influence the remittance flows from the six GCC countries. To study the effect of the explanatory variables on remittance, the results of four model specifications were explored as a benchmark. There models were: Pooled OLS estimates, Fixed effect for sending and receiving country, random effect for country-pairs and Mundlak's approach with random effects for country-pairs. Table 5 demonstrates the four models.

Table 5 Baseline Panel Gravity Model Estimates (Four Models)

\begin{tabular}{|c|c|c|c|c|}
\hline Variable & OLS & FIXED & RANDOM & MUNDLAK \\
\hline Log GDP_i & $0.616^{* * *}$ & $0.608^{* *}$ & $0.561^{* * *}$ & $0.602^{* *}$ \\
\hline Log GDP_j & $0.921^{* * *}$ & -0.233 & -0.002 & -0.259 \\
\hline Log GDP per capita_i & -0.056 & -0.291 & -0.238 & -0.285 \\
\hline Log GDP per capita_j & $2.088^{* * *}$ & $-1.662^{* * *}$ & $-1.614^{* * *}$ & $-1.648^{* * *}$ \\
\hline Log Distance & $7.519^{* * *}$ & $0.893^{* * *}$ & $9.139 * * *$ & $7.058^{* * *}$ \\
\hline Shared border & $2.422^{* * *}$ & $-.579^{*}$ & 3.027 & 1.911 \\
\hline Common language & $13.291^{* * *}$ & $10.324^{* * *}$ & $15.887^{* * *}$ & $12.222^{* * *}$ \\
\hline Common colonizer & 0.143 & -0.244 & -0.377 & 0.23 \\
\hline Constant & $-101.238^{* * *}$ & 4.896 & $-66.091^{* * *}$ & -76.051 \\
\hline Number of country-pairs & -- & -- & 48 & 48 \\
\hline Observations & 1054 & 1054 & 1054 & 1054 \\
\hline R-squared & 0.879 & 0.966 & -- & -- \\
\hline Adjusted R-squared & 0.876 & 0.964 & -- & -- \\
\hline Specific effects & None & Country (Home and Host) & Country-pair & Country-pair \\
\hline
\end{tabular}

Legend: * $p<0.05 ;{ }^{* *} p<0.01 ;{ }^{* * *} p<0.001$ GDP $i$ - Source country, GDPj- recipient country

The explanatory variables in each of the models were the logarithms of e.g. GDP and GDP per capita of the host country, GDP and GDP per capita of the recipient country, the physical distance between host and the recipient country. Moreover, non-macroeconomics variable 
including dummy variables for border sharing ( $=1$ if the country-pair share a border), sharing common language and sharing common colonizer were included. All the four models included a time fixed effect.

Fixed effect models remove the effect of time-invariant characteristics from the predictor variables in order to quantify the predictors' net effect. Once the pool OLS and the fixed effect model were fitted they were compared using a likelihood ratio test. The test was significant (Chi-squared=1318.98, p-value<0.0001) suggesting that the fixed effect model made a significant improvement. Random effect models assume that the entity's error term is not correlated with the explanatory variables, which allows for time-invariant variables to be used as explanatory variables. On the other hand, one needs to specify those individual characteristics that may or may not influence the predictor variables in a fixed effect model, which might lead to omitted variable bias if some variables are not included.

A Hausman test is normally performed to guide the choice between a fixed and a random effect model specification where the null hypothesis is that the preferred model is random effects versus the alternative, the fixed effects. Once the random effects model was fitted it was compared with the fixed effect model using the Hausman test, however, the models did not meet the asymptotic assumptions of the Hausman test and an alternative, Sargan-Hansen test, was used to make the choice. The test was significant (Sargan-Hansen statistic $=129.54$, p-value $<0.0001)$ hence the fixed effect model was chosen. The Mundlak approach estimates random effects models adding group means of variables in explanatory variables which vary within groups. It relaxes the assumption of the random-effects estimator that the observed variables are uncorrelated with the unobserved variables.

Table 5 shows the parameter estimates and the corresponding significance level for the explanatory variables in the each of the four models. The fixed effect model was as the model of choice to interpret the relationships between the explanatory variables and remittance.

Since the Fixed effect model was chosen among four models, the estimator shows a significant evidence as follows. The first result is that lager countries in GCC; those with higher GDP sent significantly higher volumes of remittances. While smaller countries; those with smaller GDP in South Asia and Middle East, received more remittances. The effect of the receiving country GDP was however not statistically significant. This result is consistent with studies Vergas-Silva and Huang (2006), Ahmed et al, (2014) Alassaf et al, (2016) and Khodeir (2015).The results indicate that remittances respond to the economic conditions in the host country, rather than that of the home country.

The second result is that Poorer countries; those with lower per capita income- received significantly more remittance flows. This finding supports earlier findings by Ramon et al (2011), Akkoyunlu and Kholodilin (2006), Vergas-Silva and Huang (2006) and Barua et al. (2007). On the other hand, the estimator show that Richer - higher GDP per capita - host countries sent lower remittances but this effect was not statistically significant.

The third result is a geographical distance between recipient countries and sources countries. It was also evident that the greater the distance between two countries, the larger the flow of remittances. This finding was consistent with Ahmed et al, (2014), IMF (2006) and Nnyanzi (2016) .These authors found that distance is not statistically significant and not an important driver of remittance flows home country because migrants utilize a wide array of informal channels to send money back home.

The fourth result was dummy variables. i). Sharing a border was significantly associated with a lower remittance flow; this could further support the theory that remittances between counties that are closer together might not be well captured as individuals might use channels that are not recognized in the main financial reporting systems. ii). Sharing a language was positively associated with remittance flows, but having a common colonizer was associated 
with reduced remittance between the countries, the later association was not statistically significant.

\section{Conclusion and Recommendations}

The study has determined the factors that influenced the nature and extent of workers' remittance flows using a case study of the Gulf Cooperation Council. The major three results show as follows. The first result displays the economic condition was a good proxy to determine migrants' remittance flows from GCC countries. Therefore, south Asian and Middle East migrants focus more on the economic conditions in GCC countries when deciding how much to remit, as an upturn in the host country increases the income earned by migrant workers and attracts more migrants looking for better income. The second result provided evidence that the differential in the wage rates between the home country and the host country had a significant positive effect on remittance flows from GCC countries. Therefore, the governments of host countries encourage migrants to hold some savings in financial assets or other investments for business re-cycling instead to send back home country. The result also demonstrates the purpose of remitting is to support family at home country. As poorer country receive more remittances. This could lead to the fact that remittance flows from GCC countries to South Asian and Middle East countries are pure altruism.

The third finding shows that distances, sharing boarding and languages between home and host countries were poor proxy to determine remittance flows from GCC countries. Counties that are closer together might not be well captured, as migrant worker might use channels that are not recognized in the main financial reporting systems.

Therefore, the governments are recommended to format the policy system of informal channels' remittances. A policy point of view, a policy of sustained economic growth will mobilize remittance savings and enable them to be directed toward productive domestic investments. Second, it could said that in order to attract remittance earnings policies have to be implemented which complement other economic policy tools.

\section{References}

Ahmed, J., \& Martinez-Zarzoso, I. (2014, June 24). What drives bilateral remittances to Pakistan? A Gravity Model Approach. (Discussion Paper No. 209). Governance and Economic Development Research.

Akkoyunlu, S., \& Kholodilin, K.A. (2006). What affects the remittances of Turkish workers: Turkish or German? Emerging Markets Finance E Trade, 44 (5), 23-40.

Al-Assaf, G., \& Al-Malki, A.M. (2014). Modelling the macroeconomic determinants of workers' remittances: The case of Jordan. International Journal of Economics and Financial Issues, 4 (3), 514.

Barua, S., Majumder, M.A., \& Akhtaruzzaman, D.M. (2007, June 30). Determinants of workers' remittances in Bangladesh: An empirical study (Working Paper No. WP 0713). Policy Analysis Unit (PAU), Bangladesh Bank.

Carling, J. (2008). The determinants of migrant remittances. Oxford Review of Economic Policy, 24(3), 581-598. doi: 10.1093/oxrep/grn022

Castillo-Ponce, R.A., Torres-Preciado, V.H., \& Manzanares-Rivera, J.L. (2011). Macroeconomic determinants of remittances for a dollarized economy: The case of El Salvador. Journal of Economic Studies, 38(5), 562-576. doi:10.1108/01443581111161823

Chowdhury, M.B. (2011). Remittances flow and financial development in Bangladesh. Economic Modelling, 28(6), 2600-2608.

Group, W.B. (2012). World Development Indicators 2012: World Bank Publications.

Guha, P. (2013). Macroeconomic effects of international remittances: The case of developing economies. Economic Modelling, 33, 292-305.

Ivlevs, A., Ziderman, A., \& Constant, A. (2016). Remittances and informal work. International Journal of Manpower, $37(7)$.

Kapiszewski, A. (2006). Arab versus Asian migrant workers in the GCC countries, presented to the United Nations Expert Group Meeting on International Migration and Development in the Arab Region, Beirut, Lebanon. 
Khodeir, A.N. (2015). Migration remittances inflows and macroeconomic shocks: The case of Egypt. International Journal of Economics and Financial Issues, 5(4).

Lueth, E.,\& Ruiz-Arranz, M. (2006). The gravity model of workers' remittances (Working Paper No. WP/06/290). International Monetary Fund.

Lueth, E., \& Ruiz-Arranz, M. (2008). Determinants of bilateral remittance flows. The BE Journal of Macroeconomics, $8(1), 1-23$.

Naufal, G.S., \& Termos, A. (2009). The responsiveness of remittances to price of oil: The case of the GCC. OPEC Energy Review, 33(3/4), 184-197. doi: 10.1111/j.1753-0237.2009.00166.x

Nnyanzi, J.B. (2016). What drives international remittances to Africa: Altruism, self-interest or the institutional environment? African Journal of Economic and Management Studies, 7(3). doi:10.1108/ AJEMS-07-2013-0067

Ratha, D., Mohapatra, S., \& Silwal, A. (2009). Migration and remittance trends 2009: A better-than-expected outcome so far, but significant risks ahead, Migration and Development Brief No. 11, Washington, DC: World Bank.

Shah, N.M. (2006). Restrictive labour immigration policies in the oil-rich gulf: Effectiveness and implications for sending Asian countries, presented at the UN Expert Group Meeting on International Migration and Development in the Arab Region: Challenges and Opportunities, Beirut, Lebanon.

Taghavi, M. (2012). The impact of workers' remittances on macro indicators: The case of the Gulf Cooperation Council. Topics in Middle Eastern and African Economies, 14, 49-73.

Vargas-Silva, C., \& Huang, P. (2006). Macroeconomic determinants of workers' remittances: Host versus home country's economic conditions. Journal of International Trade and Economic Development, 15(1), 81-99. 